\title{
Effect of a horse's month of birth on its future sport performance. I. Effect on annual phenotypic indices
}

\author{
B Langlois*, C Blouin \\ Station de génétique quantitative et appliquée, Inra, 78352 Jouy-en-Josas cedex, France
}

(Received 8 November 1996; accepted 20 April 1997)

\begin{abstract}
Summary - This study examined the effect of month of birth on performance in flat races, steeplechase and hurdle races, harness racing, and equestrian competitions (jumping, 3-day events, dressage). The performance was evaluated by considering the annual phenotypic indices calculated from their earnings and published by the SIRE (Système d'Identification Répertoriant les Equidés): ICP for flat races, ICO for the steeplechases and hurdle races, ITR for trotting races, ISO for jumping, ICC for the Olympic 3-day event and ICD for dressage. The effect of month of birth was tested through variance analysis and was significant in every case. Horses that are born early in the year had an advantage and performed better than horses born later. The effect varied in magnitude with the different disciplines. It was marked in flat races and trotting races, and lower in the steeplechases and Olympic sport disciplines. The effect decreased with age, but remained significant very late in a horse's career. In conclusion, an early birth month is advantageous for a horse and application of winter lighting protocols for mares should take this into consideration. Because of its statistical significance, this effect should be routinely taken into account in breeding value estimation, particularly for racing activities.
\end{abstract}

horse / effect of month of birth / sport performance

Résumé - Effet du mois de naissance sur les performances des chevaux. I. Effet sur les indices phénotypiques annuels. L'effet du mois de naissance sur les performances en course plate et à obstacles, en course au trot et en compétitions équestres a été examiné. La mesure des performances a été réalisée, par les différents indices phénotypiques annuels publiés par le Siret : ICP pour le plat, ICO pour l'obstacle, ITR pour le trot, ISO pour le concours hippique, ICC pour le concours complet et ICD pour les concours de dressage. L'effet du mois de naissance testé par l'analyse de la variance s'avère significatif dans tous les cas. Les chevaux nés précocement sont avantagés alors que les naissances tardives sont désavantagées. L'effet est plus ou moins marqué selon les disciplines. D'une certaine ampleur en course plate et au trot, il est moins marqué en courses à obstacles et en compétitions équestres. La répartition des performances par âge montre que cet effet s'amenuise avec l'âge mais

* Correspondence and reprints

Tel: 01346521 10; fax:01 34652130 
reste sensible jusqu'à des âges souvent avancés. On conclut sur l'intérêt des naissances précoces pour toutes les disciplines sportives et l'avantage pratique que fournissent les protocoles d'éclairement nocturne des juments pendant l'hiver pour les obtenir. L'importance de cet effet mérite qu'il soit introduit en routine pour l'estimation des valeurs génétiques particulièrement dans le cas des courses.

\section{cheval / effet du mois de naissance / performance sportive}

\section{INTRODUCTION}

It is very common to hear about the advantages and disadvantages of a foal being born early versus late in the year. It is also logical to think that in the same 'administrative' age class (determined on the Ist of January), real age differences may exist. This should influence performance, particularly in disciplines such as races where performance is asked from the young animals. Saastamoinen and Ojala (199I) published a study on this problem for trotters in Finland. Physick-Sheard (1986) mentioned also the question for Canadian trotters. One study by Ruane and Cunningham (1987) was published on thoroughbreds but we have not found any reports concerning sport horses. The purpose of this study was therefore to make a first rough analysis of the large French data sets which cover galloping and trotting races and also Olympic sport disciplines.

\section{MATERIALS AND METHODS}

The different performance indexes published in the French stud-books and diffused through the press and the Minitel phone network were used to measure the performance. These annual indexes (Langlois, 1993) are compilations of the annual earning, and produce normally distributed values with a mean of 100 and standard deviation of 20. Theses indexes are corrected in the year of performance for administrative age and sex. According to the first studies, no interactions are assumed to exist between age and sex (Langlois, 1975a,b, 1980, 1989).
Usual abbreviations are:

- flat race earnings, ICP (indice course plate)

- earnings over the jumps, ICO (indice course à obstacles)

- earnings per start in trotting, ITR (indice trot)

- earnings in jumping, ISO (indice saut d'obstacles)

- earnings in 3-day events, ICC (indice concours complet)

- earnings in dressage, ICD (indice concours de dressage)

The effect of month of birth on performance was tested through a very simple model (one fixed effect) run on SAS-GLM. This approach accounted for interactions between year of performance and age or sex but ignored potential interactions between month of birth and age or sex. We therefore analyzed the data per age classes to check for potential interactions between month of birth and age. The number of observations covering the years 1985 to 1994 in each data set analyzed was large (tables I--VI). The birth month April was chosen as the reference for comparison. Age class subsets are those commonly used for indexation. They are so as to equilibrate the numbers per level for each year.

\section{RESULTS}

The effect of birth month on performance was highly significant in all the examined disciplines.

For galloping races, it can be seen from tables I and II that the earlier a horse is born in the year the more successful he is. Also, the advantage of being born early slowly decreases with age up to 5 years and older where it is no longer significant. The magnitude of the effect was also greater for flat races than for jumping races and competitions which concern mainly older horses. 
Table I. Effect of month of birth on the performances in flat races measured by the ICP.

\begin{tabular}{lccccc}
\hline & $\begin{array}{c}\text { Overall } \\
\text { material }\end{array}$ & $\begin{array}{c}2 \text { years } \\
\text { old }\end{array}$ & $\begin{array}{c}\text { 3 years } \\
\text { old }\end{array}$ & $\begin{array}{c}4 \text { years } \\
\text { old }\end{array}$ & $\begin{array}{c}5 \text { years old } \\
\text { and older }\end{array}$ \\
\hline Intercept & $99.4(0.2)$ & $98.0(0.4)$ & $99.1(0.3)$ & $100.1(0.4)$ & $100.5(0.4)$ \\
Month of birth & & & & & \\
$\quad$ December & $4.0(4.1)$ & $8.5(5.1)$ & $3.4(7.1)$ & $-12.6(14.5)$ & - \\
$\quad$ January-February & $2.4(0.3)$ & $2.9(0.6)$ & $3.5(0.5)$ & $2.4(0.7)$ & $0.1(0.6)$ \\
$\quad$ March & $1.1(0.3)$ & $1.5(0.5)$ & $1.7(0.4)$ & $0.8(0.6)$ & $0.3(0.5)$ \\
April & 0.0 & 0.0 & 0.0 & 0.0 & 0.0 \\
$\quad$ May & $-0.9(0.3)$ & $-1.5(0.6)$ & $-1.5(0.5)$ & $-0.7(0.7)$ & $-0.3(0.6)$ \\
$\quad$ June and later & $-2.1(0.6)$ & $-4.5(1.7)$ & $-3.8(1.1)$ & $-1.5(1.4)$ & $-0.3(1.1)$ \\
Number & 40861 & 8022 & 15427 & 7796 & 9613 \\
Global significance & $* * *$ & $* * *$ & $* * *$ & $* * *$ & $\mathrm{~ns}$ \\
\hline
\end{tabular}

Between parentheses is the standard error of estimate.

Table II. Effect of month of birth on the performances in steeple-chases and hurdle races measured by the ICO.

\begin{tabular}{lccccc}
\hline & $\begin{array}{c}\text { Overall } \\
\text { material }\end{array}$ & $\begin{array}{c}3 \text { years } \\
\text { old }\end{array}$ & $\begin{array}{c}4 \text { years } \\
\text { old }\end{array}$ & $\begin{array}{c}5 \text { years } \\
\text { old }\end{array}$ & $\begin{array}{c}\text { 6 years old } \\
\text { and older }\end{array}$ \\
\hline $\begin{array}{l}\text { Intercept } \\
\text { Month of birth }\end{array}$ & $100.6(0.3)$ & $100.4(0.5)$ & $100.8(0.5)$ & $100.6(0.6)$ & $100.5(0.4)$ \\
$\quad$ January-February & $0.8(0.4)$ & $1.4(0.9)$ & $1.1(0.9)$ & $1.8(1.1)$ & $-1.0(0.8)$ \\
$\quad$ March & $1.0(0.4)$ & $1.4(0.8)$ & $1.3(0.8)$ & $1.4(0.9)$ & $0.2(0.7)$ \\
$\quad$ April & 0.0 & 0.0 & 0.0 & 0.0 & 0.0 \\
May & $-0.9(0.4)$ & $-2.6(0.8)$ & $-1.4(0.8)$ & $-0.6(0.9)$ & $0.3(0.6)$ \\
$\quad$ June and later & $-1.9(0.7)$ & $-5.9(1.7)$ & $-3.0(1.6)$ & $-0.6(1.7)$ & $-0.3(1.2)$ \\
Number & 20050 & 4560 & 5356 & 3655 & 6479 \\
Global significance & $* * *$ & $* * *$ & $* *$ & $\mathrm{~ns}$ & $\mathrm{~ns}$ \\
\hline
\end{tabular}

Between parentheses is the standard error of estimate.

These results did not confirm the conclusions of Ruane and Cunningham (1987) on time form ratings obtained with a small data set.

For trotting performances (table III), the effect of birth month showed a similar pattern as for flat races for young animals of 2 and 3 years. The main difference was that the diminishing effect with age remained significant up to 6 years. This was not the case in galloping races. This is difficult to explain using only real age differences between animals of the same administrative age class. These results confirmed those of Saastamoinen and Ojala (1991) and invalidated the observations of Physick-Sheard (1986) working with a very small data set.

Effect of month of birth on performance in jumping is shown in table IV. The effect was less pronounced than in racing but it was also highly significant. In jumping, the 
Table III. Effect of month of birth on the performances in harness races measured by the ITR.

\begin{tabular}{lcccccc}
\hline & $\begin{array}{c}\text { Overall } \\
\text { material }\end{array}$ & $\begin{array}{c}2 \text { years } \\
\text { old }\end{array}$ & $\begin{array}{c}3 \text { years } \\
\text { old }\end{array}$ & $\begin{array}{c}4 \text { years } \\
\text { old }\end{array}$ & $\begin{array}{c}5 \text { years } \\
\text { old }\end{array}$ & $\begin{array}{c}6 \text { years old } \\
\text { and older }\end{array}$ \\
\hline $\begin{array}{l}\text { Intercept } \\
\text { Month of birth }\end{array}$ & $100.9(0.2)$ & $100.9(0.5)$ & $101.8(0.2)$ & $101.0(0.2)$ & $100.5(0.3)$ & $100.0(0.2)$ \\
$\quad$ January-February & $2.7(0.3)$ & $3.6(1.1)$ & $3.6(0.5)$ & $3.5(0.5)$ & $0.6(0.3)$ & $1.7(0.6)$ \\
$\quad$ March & $0.7(0.2)$ & $0.9(0.8)$ & $1.3(0.3)$ & $1.0(0.3)$ & $0.1(0.7)$ & $-0.4(0.4)$ \\
$\quad$ April & 0.0 & 0.0 & 0.0 & 0.0 & 0.0 & 0.0 \\
$\quad$ May & $-0.9(0.2)$ & $-0.6(0.7)$ & $0.6(0.3)$ & $-1.3(0.3)$ & $-1.4(0.4)$ & $-0.6(0.3)$ \\
$\quad$ June and later & $-1.7(0.1)$ & $-2.3(1.2)$ & $-2.3(0.4)$ & $-1.9(0.5)$ & $-1.7(0.6)$ & $-0.6(0.5)$ \\
Number & 93089 & 4369 & 25593 & 24727 & 16400 & 22000 \\
Significance & $* * *$ & $* * *$ & $* *$ & $* * *$ & $* * *$ & $* *$ \\
\hline
\end{tabular}

Between parentheses is the standard error of estimate.

Table IV. Effect of month of birth on the performances in jumping measured by the ISO.

\begin{tabular}{lcccccc}
\cline { 6 - 8 } & $\begin{array}{c}\text { Overall } \\
\text { material }\end{array}$ & $\begin{array}{c}4 \text { years } \\
\text { old }\end{array}$ & $\begin{array}{c}5 \text { years } \\
\text { old }\end{array}$ & $\begin{array}{c}6,7 \text { years } \\
\text { old }\end{array}$ & $\begin{array}{c}8,9,10 \text { years } \\
\text { old }\end{array}$ & $\begin{array}{c}11 \text { years old } \\
\text { and older }\end{array}$ \\
\hline $\begin{array}{l}\text { Intercept } \\
\text { Month of birth }\end{array}$ & $100.2(0.1)$ & $100.2(0.2)$ & $100.1(0.2)$ & $100.1(0.2)$ & $100.1(0.2)$ & $100.7(0.2)$ \\
$\quad$ & & & & & \\
$\quad$ January-February & $0.5(0.2)$ & $1.0(0.4)$ & $0.3(0.5)$ & $1.1(0.4)$ & $0.2(0.4)$ & $-0.1(0.5)$ \\
$\quad$ March & $0.3(0.1)$ & $0.3(0.3)$ & $0.4(0.3)$ & $0.4(0.3)$ & $0.3(0.3)$ & $-0.3(0.3)$ \\
$\quad$ April & 0.0 & 0.0 & 0.0 & 0.0 & 0.0 & 0.0 \\
$\quad$ May & $-0.3(0.1)$ & $0.1(0.3)$ & $-0.1(0.3)$ & $-0.3(0.2)$ & $-0.4(0.3)$ & $-0.8(0.3)$ \\
$\quad$ June and later & $-0.4(0.2)$ & $0.1(0.4)$ & $-0.5(0.4)$ & $-0.3(0.4)$ & $-0.1(0.4)$ & $-1.7(0.6)$ \\
Number & 156490 & 17918 & 24193 & 43671 & 44129 & 26579 \\
Significance & $* * *$ & $\mathrm{~ns}$ & $\mathrm{~ns}$ & $* *$ & $\mathrm{~ns}$ & $*$ \\
\hline
\end{tabular}

Between parentheses is the standard error of estimate.

advantage of early born horses was relatively weak at 4 years of age but it remained up to 6 and 7 years and disappeared after this time. On the other hand, the disadvantage of late born horses, which was not so large at 4 years, lasted throughout the horses career.

Such a situation could be also observed for the 3-day events where it was even more accentuated (table V). No advantage was observed for early born horses but it was clear that horses born in May, June and later were not as successful. This disadvantage increased with age as the performances become more meaningful (up to 8 years).

For dressage it can be seen from table VI that early born horses had a clear advantage. This advantage also increased with age as the performances became more meaningful ( 8 to 10 years) 
Table V. Effect of month of birth on the performances in three days event measured by the ICC.

\begin{tabular}{lccccc}
\hline & $\begin{array}{c}\text { Overall } \\
\text { material }\end{array}$ & $\begin{array}{c}4,5 \text { years } \\
\text { old }\end{array}$ & $\begin{array}{c}6,7 \text { years } \\
\text { old }\end{array}$ & $\begin{array}{c}8,9, \text { lo years } \\
\text { old }\end{array}$ & $\begin{array}{c}\text { 11 years old } \\
\text { and older }\end{array}$ \\
\hline Intercept & $100.5(0.2)$ & $100.7(0.5)$ & $99.8(0.4)$ & $100.5(0.5)$ & $101.4(0.6)$ \\
Month of birth & & & & & \\
$\quad$ January-February & $-0.5(0.6)$ & $-1.1(1.2)$ & $1.2(1.0)$ & $-0.2(1.0)$ & $-2.8(1.3)$ \\
$\quad$ March & $-0.0(0.4)$ & $-1.3(0.9)$ & $0.7(0.7)$ & $0.4(0.7)$ & $-0.9(0.9)$ \\
April & 0.0 & 0.0 & 0.0 & 0.0 & 0.0 \\
May & $-1.0(0.4)$ & $-0.6(0.8)$ & $0.3(0.6)$ & $-1.5(0.7)$ & $-2.2(0.9)$ \\
$\quad$ June and later & $-2.7(0.7)$ & $-1.5(1.4)$ & $-1.6(1.0)$ & $-3.5(1.3)$ & $-3.6(1.7)$ \\
Number & 17990 & 2136 & 5735 & 6179 & 3940 \\
Global significance & $* * *$ & $\mathrm{~ns}$ & $\mathrm{~ns}$ & $*$ & $*$ \\
\hline
\end{tabular}

Between parentheses is the standard error of estimate.

Table VI. Effect of month of birth on the performances in dressage measured by the ICD.

\begin{tabular}{lccccc}
\hline & $\begin{array}{c}\text { Overall } \\
\text { material }\end{array}$ & $\begin{array}{c}4,5 \text { years } \\
\text { old }\end{array}$ & $\begin{array}{c}6,7 \text { years } \\
\text { old }\end{array}$ & $\begin{array}{c}8,9,10 \text { years } \\
\text { old }\end{array}$ & $\begin{array}{c}\text { I1 vears old } \\
\text { and older }\end{array}$ \\
\hline Intercept & $99.0(0.3)$ & $100.8(0.8)$ & $99.4(0.6)$ & $98.6(0.5)$ & $98.3(1.6)$ \\
Month of birth & & & & & \\
$\quad$ January-February & $2.4(0.7)$ & $-0.5(2.0)$ & $1.4(1.5)$ & $3.6(1.2)$ & $2.9(1.3)$ \\
$\quad$ March & $-0.6(0.5)$ & $-0.5(1.3)$ & $-1.9(1.1)$ & $-1.2(0.9)$ & $0.7(0.9)$ \\
April & 0.0 & 0.0 & 0.0 & 0.0 & 0.0 \\
May & $0.3(0.5)$ & $-1.5(1.1)$ & $-0.8(0.9)$ & $-0.6(0.8)$ & $0.9(0.9)$ \\
$\quad$ June and later & $0.8(0.8)$ & $-1.8(1.9)$ & $-0.9(1.6)$ & $0.9(1.4)$ & $3.1(1.5)$ \\
Number & 11012 & 1450 & 2379 & 3692 & 3489 \\
Global significance & $* *$ & $\mathrm{~ns}$ & $\mathrm{~ns}$ & $* *$ & $\mathrm{~ns}$ \\
\hline
\end{tabular}

Between parentheses is the standard error of estimate.

\section{DISCUSSION AND CONCLUSION}

The effect of birth month was found to be highly significant in all the disciplines studied. It is therefore necessary to correct for this factor of variation in breeding value estimations. This is particularly the case for disciplines based on early performances obtained at 2 and 3 years. Because real age may vary by several months in the same administrative age class, one could recom- mend correcting the data to reflect the age in months. Residual effects of month of birth would in this case represent another phenomenon. But this analysis is only possible for performance records at the level of race or competition. For summarized performance data at the year level, correction of birth month is the only possibility.

It is remarkable that this effect of birth month often persisted up to an advanced age. In these cases, the age advantage is no 
longer a very convincing argument, and a real biological effect is thus a possibility.

To explain the advantage of early birth (except with month differences in the same administrative age class), one can consider the benefit of housing the foal at the beginning of his life: positive nutritional effects on the mare; prevention of skeleton injuries for the foal. In addition, positive ethological conditioning of the foal is possible due to the human contact in the stable.

The disadvantage of late birth (except the age disadvantage) can include poorer grazing conditions for the mares in late spring and summer causing poorer lactation during the period of the foal' maximal requirements. The young foal is rapidly outdoors after birth and therefore galloping and playing hard in the first month of his life. This can be at the origin of skeletal injuries. Human contact is rare and this is not favorable to ethological conditioning.

Month of birth can also be partly confused with other effects not thoroughly analyzed at this time (Hintz et al, 1979). These include the age of the dam and the length of gestation. Late born horses have a greater chance of having older dams and a shorter length of gestation. Younger mares tend to have their foals earlier in the year and have longer gestation periods. (Howell and Rollins, 1951).

In conclusion, more study is needed on this question. One well-established fact is that under our management conditions there is undoubtedly an advantage to horses born early in the year. Therefore, managing mares with lighting protocols during winter (Guillaume et al, 1996) not only offers the possibility of increasing fertility by increasing the number of cycles available for mating during the breeding season but it will also increase success of the foals, as they are produced earlier.

\section{REFERENCES}

Guillaume D, Duchamp G, Palmer E (1996) Trentecing jours longs suffisent pour avancer et établir la cyclicité des juments en inactivité hivernale. Compte rendu de la $22^{e}$ Journée de la recherche équine. Paris 28 février 1996, 2-7

Hintz HF, Hintz RL, Van Vleck LD (1979) Growth rate of thoroughbreds, effect of age of dam, year and month of birth. J Anim Sci 48, 480-487

Howell CE, Rollins WC (1951) Environmental sources of variation in the gestation length of the horse. J Anim Sci 10, 789-796

Langlois B. (1975a) Analyse statistique et génétique: des gains des pur sang anglais de trois ans dans les courses plates françaises. Anm Génét Sél Anim 7. $387-408$

Langlois B (1975b) Interprétation statistique et génétique des gains des chevaux dans les compétitions. équestres françaises. Livest Prod Sci 2, 191-204

Langlois B (1980) Estimation de la valeur génétique des chevaux de sport d'après les sommes gagnées dans les compétitions équestres françaises. Ann Génét Sél Anim 12, 15-31

Langlois B (1989) Breeding evaluation of French trotters according to their race earnings. 1. Present situation. EAAP Publication, Pudoc Wageningen, the Netherlands, no 42, 24-40

Langlois B (1993) Registration systems concerning breeding and performance. The situation of France. 44th Annual Meeting Europ Assoc Anim Prod, 16-19 August 1993, Aarhus, Denmark, Commission on Horse production, session II, $4 \mathrm{p}$

Physick-Sheard PW (1986) Career profile of the Canadian Standard bred 1. Influence of age gait and sex upon chances of racing. Canad $J$ Vet Res 50 , $449-456$

Ruane J, Cunningham EP (1987) Does birth date affect performance or price. The Irish Field, February 14th, 1987

Saastamoinen MT, Ojala MJ (1991) Influence of birthmonth on age at first start and racing performance in young trotters. Acta Agric Scand 41, 437-445 